\title{
Quem me tira de mim e me dá vozes?
}

Quando não se é escritor, é desassossego escrever sobre o escritor que se admira. Antes de começar a alinhar com tamanha dificuldade as palavras, abro ao acaso o livro da adivinhação Da Rosa Fixa:

130. O alimento a legar será simples como uma palavra de desordem.

Calhou-me a recomendação mais breve e certeira. A primeira edição é de 1978 e foi-me oferecida com dedicatória por Maria Velho da Costa, que conhecera meses atrás. Antes dera-me as páginas manuscritas a lápis (primeira versão) de um texto construído para Ninguém - Frei Luís de Sousa, um espectáculo de Ricardo Pais: as páginas da dupla de Maria, a sua escrava-irmã - "Eu vivi nessas terras onde a morte era a morte, o tempo era o tempo, e tudo tinha nome [...]" - cito de cor, por muito que as repeti. Fátima, Ricardo e eu, à mesa de camilha no andar da rua de São Bento. Por esses dias fui enlaçado no mistério da paixão pela sua escrita a cada edição. Cedo tomei consciência da minha incompletude caso não mergulhasse com urgência no próximo livro a ler, dentro de uma nova e surpreendente arquitectura por descobrir e habitar. Aprendi-lhe o ritmo ao ouvi-la ler em voz alta. Nunca me custou respirar os textos dessa escrita diversa e ancestral, cheia de vozes que acrescentam sons, luzes, cores, matizes, que antes apenas intuíra; aprendizagens que revelam paisagens, retratos e afectos em composições desgarradas da tradição formal, iluminados em manhã que sucede à noite passada em claro. As mulheres e os homens a serem revelados pelos olhos e ouvidos da escrita, nova de livro para livro - novos e velhos, ricos e pobres, nativos, emigrantes e estrangeirados, respectivas línguas a migrarem com eles. Gente!

Quando me chegou a nefasta notícia da sua morte, peguei de novo em Da Rosa Fixa e abri ao acaso, como a autora me recomendara há quarenta e dois anos:

19. Alegria: doravante murmurarei só diante da abundância dos teus gestos falantes tão alto, cantos.

Recado de vida que me impele a continuar. Não era suposto que um texto de lembrança em vida fosse concluído após a morte daquela que se queria homenagear. Foi um círculo que 
se quebrou, e ficam os vivos a falar uns com os outros, testemunhando uma admiração comum sem corpo presente. MVC retirou-se da escrita por vontade própria, cumprindo o "tenho dito!" que tantos prometem mas não cumprem. Habituou os seus leitores à espera e depois ao luto lento, mais de uma década antes de deixar de estar. Que a sua obra continue a ecoar pelos corredores do tempo junto daqueles que querem saber da sua/nossa condição e de que terra fomos/somos. Mas se tão poucos contemporâneos a terão lido, como será?

Quando pus em cena Casas Pardas no Teatro Nacional São João (2012), fi-lo com muito temor, pelo respeito que tinha às palavras e a quem e como as escrevera. Estávamos a pegar no livro de história natural da nossa era (aquele que já trazia o Teatro dentro) e que Luísa Costa Gomes tão bem compôs na sua dramaturgia. (Leia-se o Manual de Leitura do espectáculo para avaliar do cometimento de toda a equipa). Creio que MVC terá sentido que aquilo a que assistiu da plateia lhe pertencia por inteiro, apesar da apropriação e figuração alheias. Foi esse o momento da minha devolução devota: dar a ver a sua escrita na nossa tradução cénica.

Agora que ficou um lugar "sob luz intensíssima" à mesa das palavras, vou continuar a dever-lhe a exigência e lucidez do "tenho dito!". 